\title{
A Predictive Model for Steady State Ozone Concentration at an Urban-Coastal Site
}

\author{
Mansour A. Alghamdi ${ }^{1}$, Afnan Al-Hunaiti ${ }^{2}$, Sharif Arar ${ }^{2}$, Mamdouh Khoder ${ }^{1}$, \\ Ahmad S. Abdelmaksoud ${ }^{1}$, Hisham Al-Jeelani ${ }^{1}$, Heikki Lihavainen ${ }^{3}$, Antti Hyvärinen ${ }^{3}$, \\ Ibrahim I. Shabbaj ${ }^{1}$, Fahd M. Almehmadi ${ }^{1}$, Martha A. Zaidan ${ }^{4}$, Tareq Hussein ${ }^{4,5}$ (D) \\ and Lubna Dada ${ }^{4, *(1)}$ \\ 1 Department of Environmental Sciences, Faculty of Meteorology, Environment and Arid Land Agriculture, \\ King Abdulaziz University, P.O. Box 80208, Jeddah 21589, Saudi Arabia; mghamdi2@kau.edu.sa (M.A.A.); \\ khoder_55@yahoo.com (M.K.); asabdelmaksoud@yahoo.com (A.S.A.); hjeelani@gmail.com (H.A.-J.); \\ ishabbaj@yahoo.com (I.I.S.); fmehmadi@gmail.com (F.M.A.) \\ 2 Department of Chemistry, University of Jordan, Amman 11942, Jordan; a.alhunaiti@ju.edu.jo (A.A.-H.); \\ s.arar@ju.edu.jo (S.A.) \\ 3 Finnish Meteorological Institute, Erik Palménin aukio 1, FI-00101 Helsinki, Finland; \\ heikki.lihavainen@fmi.fi (H.L.); antti.hyvarinen@fmi.fi (A.H.) \\ 4 Institute for Atmospheric and Earth System Research (INAR), University of Helsinki, \\ FI-00014 Helsinki, Finland; martha.zaidan@helsinki.fi (M.A.Z.); tareq.hussein@helsinki.fi (T.H.) \\ 5 Department of Physics, University of Jordan, Amman 11942, Jordan \\ * Correspondence: Lubna.dada@helsinki.fi; Tel.: +358504488568
}

Received: 27 September 2018; Accepted: 15 January 2019; Published: 17 January 2019

\begin{abstract}
Ground level ozone $\left(\mathrm{O}_{3}\right)$ plays an important role in controlling the oxidation budget in the boundary layer and thus affects the environment and causes severe health disorders. Ozone gas, being one of the well-known greenhouse gases, although present in small quantities, contributes to global warming. In this study, we present a predictive model for the steady-state ozone concentrations during daytime (13:00-17:00) and nighttime (01:00-05:00) at an urban coastal site. The model is based on a modified approach of the null cycle of $\mathrm{O}_{3}$ and $\mathrm{NO}_{x}$ and was evaluated against a one-year data-base of $\mathrm{O}_{3}$ and nitrogen oxides $\left(\mathrm{NO}\right.$ and $\left.\mathrm{NO}_{2}\right)$ measured at an urban coastal site in Jeddah, on the west coast of Saudi Arabia. The model for daytime concentrations was found to be linearly dependent on the concentration ratio of $\mathrm{NO}_{2}$ to $\mathrm{NO}$ whereas that for the nighttime period was suggested to be inversely proportional to $\mathrm{NO}_{2}$ concentrations. Knowing that reactions involved in tropospheric $\mathrm{O}_{3}$ formation are very complex, this proposed model provides reasonable predictions for the daytime and nighttime concentrations. Since the current description of the model is solely based on the null cycle of $\mathrm{O}_{3}$ and $\mathrm{NO}_{x}$, other precursors could be considered in future development of this model. This study will serve as basis for future studies that might introduce informing strategies to control ground level $\mathrm{O}_{3}$ concentrations, as well as its precursors' emissions.
\end{abstract}

Keywords: chemical coupling; nitrogen oxides; ozone; weekend effect

\section{Introduction}

Tropospheric ozone $\left(\mathrm{O}_{3}\right)$ is known for causing severe health effects and having environmental impacts [1,2]. Among other photochemical oxidants, $O_{3}$ is one of the widely studied subjects worldwide under the category of air pollution. Besides that, $\mathrm{O}_{3}$ is a key precursor of hydroxyl radicals $(\mathrm{OH})$, which control the oxidizing power of the lower atmosphere and by that alters its chemical properties [3].

Ground level $\mathrm{O}_{3}$ formation depends on photochemistry, meteorological conditions, and air mass transport [4-7]. For instance, $\mathrm{O}_{3}$ is found to peak during the summer time accompanying high 
temperatures and long daytime hours and thus seems to be correlated with solar radiation intensity [8-13]. In urban environments, the diurnal cycle of $\mathrm{O}_{3}$ consists of nighttime low concentrations and daytime high concentrations, which may last for several hours (Figure 1). This high $\mathrm{O}_{3}$ concentration during the daytime is mainly attributed to photochemical reactions mainly within the $\mathrm{NO}_{x}-\mathrm{O}_{3}$ cycle. The low $\mathrm{O}_{3}$ concentrations during nighttime are the result of the pause in ozone production, due to the absence of photochemical reactions. Eventually, the $\mathrm{O}_{3}$ is recycled through chemical reactions or is lost by deposition [14]. It is interesting that the daytime steady-state $\mathrm{O}_{3}$ concentration on weekends is higher than that on workdays. The latter can be attributed to higher traffic on workdays than on weekends, releasing more $N O_{x}$, which in turn uses up the daytime available ozone, leaving behind a lower concertation of steady state ozone on workdays. The aforementioned assumptions are discussed in more detail in the following sections. Being the major source of daytime ground level $\mathrm{O}_{3}$, we believe that the $\mathrm{NO}_{x}-\mathrm{O}_{3}$ null cycle, can be applied to predict the steady-state daytime $\mathrm{O}_{3}$ concentrations in urban areas.

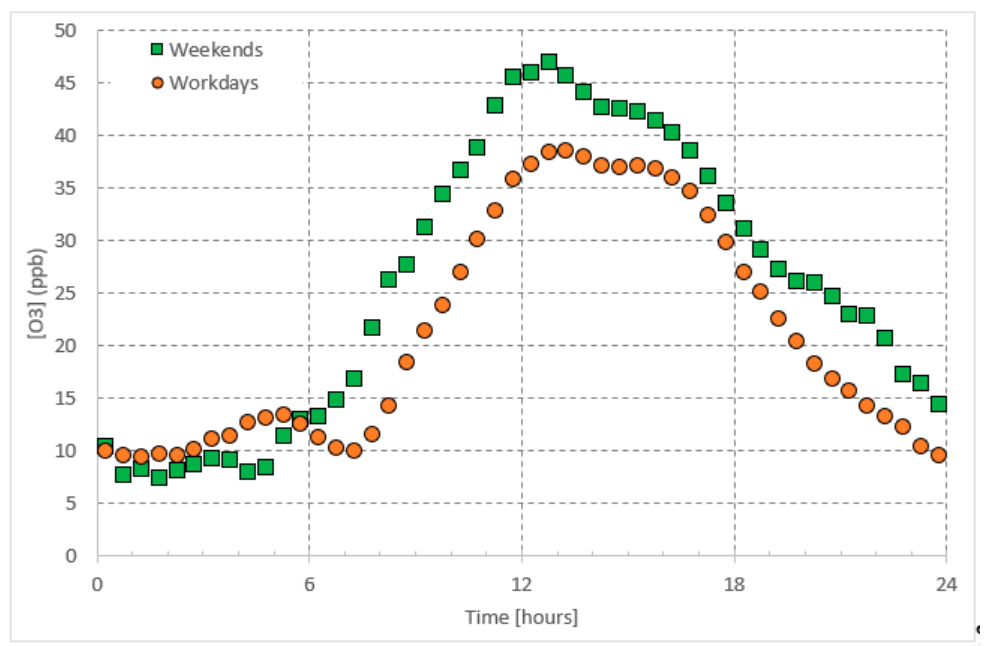

Figure 1. Average daily pattern of $\mathrm{O}_{3}$ presented separately for workdays and weekends.

The momentary change rate of $\mathrm{O}_{3}$ concentrations can be described by its sources and sinks involved in atmosphere $[15,16]$. For instance, in urban environments, $O_{3}$ is formed through a series of daytime reactions that involve $\mathrm{NO}_{x}\left(\mathrm{NO}\right.$ and $\left.\mathrm{NO}_{2}\right)$, which are of anthropogenic origin. Other sources of $\mathrm{O}_{3}$ include volatile organic compounds (VOCs) and carbon monoxide (CO) [17]. The priority of the reactions depends on the concentrations of $N O_{x}$ and VOCs, as well as the ratio of the two $\left(\mathrm{NO}_{x} / V O C\right)$ [18]. Accordingly, two regimes for $\mathrm{O}_{3}$ formation have been proposed. The first one is the $\mathrm{NO}_{x}$-sensitive regime in which the increase in $\mathrm{NO}_{x}$ concentration causes an increase in $\mathrm{O}_{3}$ concentration and the formation of $\mathrm{O}_{3}$ is mainly independent of the VOCs concentration. The second one is the $V O C$-sensitive regime in which the $\mathrm{O}_{3}$ formation is solely dependent on the VOCs concentration $[19,20]$. Therefore, the prevailing regime is specific to the dominant environmental conditions.

In the urban atmosphere, $\mathrm{NO}$ and $\mathrm{NO}_{2}$ are emitted from anthropogenic activities, including combustion processes (e.g., traffic and industrial activities). Their daily patterns (Figures 2 and 3) are, therefore, controlled by these emissions [21-23]. Since $N O$ is a primary pollutant and acts to form $\mathrm{NO}_{2}$ upon a series of reactions [24], the $\mathrm{NO}_{2}$ morning peak appears one hour later than the $\mathrm{NO}$ peak. The $N O_{x}$ concentrations vary between morning and evening and the change is attributed to many factors. First, during the early hours of daytime, high traffic emissions are accumulated in the atmosphere when the photo-chemically produced $\mathrm{O}_{3}$ concentrations are still low; $\mathrm{O}_{3}$ acts as a sink for both $\mathrm{NO}$ and $\mathrm{NO}_{2}$. Concurrent with sunrise, these pollutants are consumed with daytime produced $\mathrm{O}_{3}$ and are subject to thermal turbulence, due to higher temperature resulting in their dilution, dispersion within expansion in the boundary layer and eventually a drop in their concentrations $[25,26]$. On the 
other hand, along with sunset $\mathrm{NO}$ and $\mathrm{NO}_{2}$ encounter lower temperature, less boundary layer mixing and low dispersion leading to an increase in their concentrations.

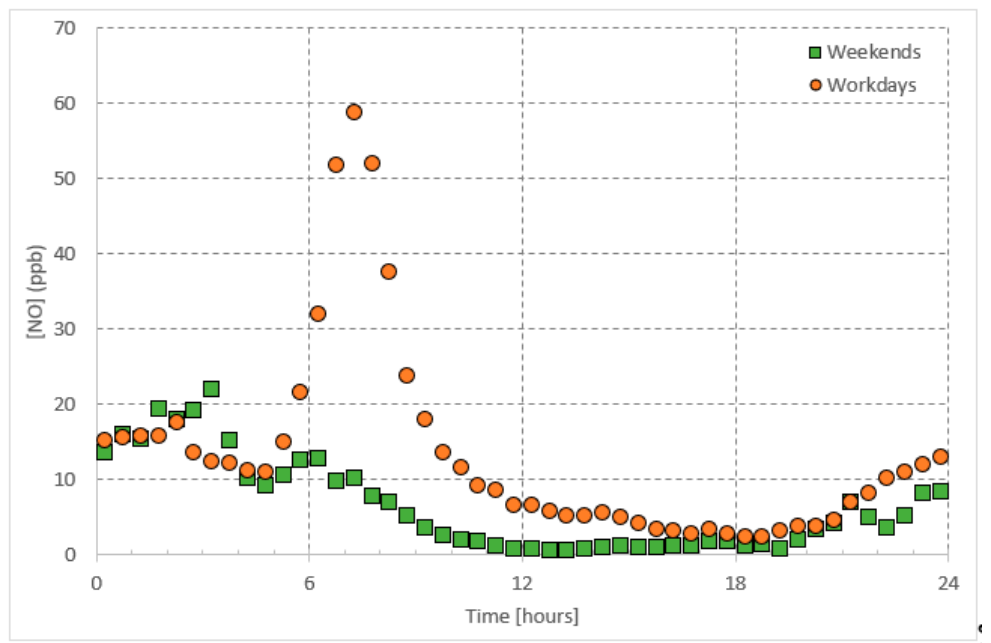

Figure 2. Average daily pattern of $N O$ presented separately for workdays and weekends.

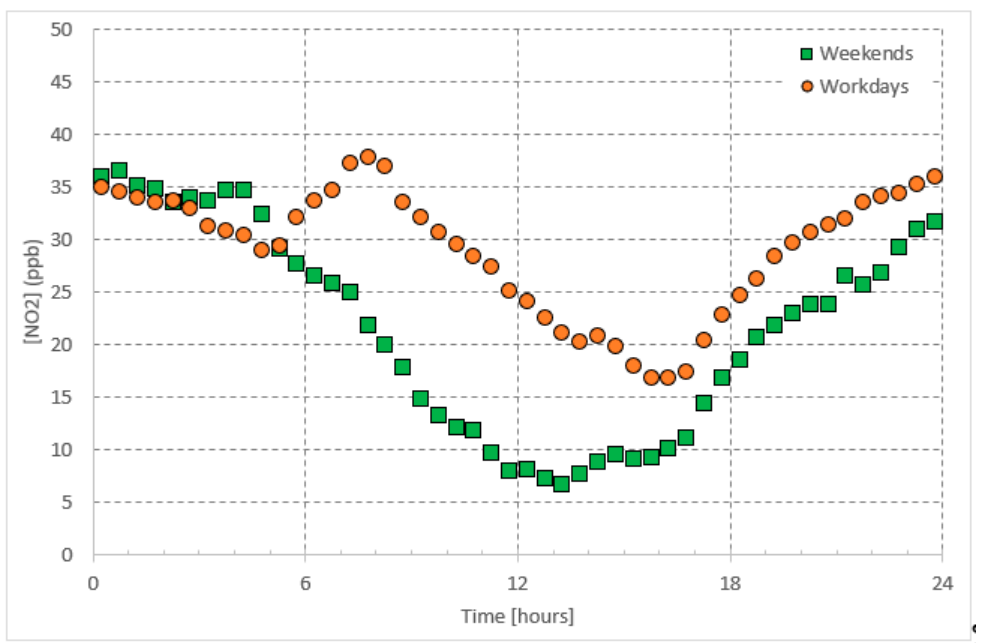

Figure 3. Average daily pattern of $\mathrm{NO}_{2}$ presented separately for workdays and weekends.

The characteristics and patterns of ground level $\mathrm{O}_{3}$ have been the subject of many studies worldwide [27]. Specifically, the chemical coupling between $\mathrm{O}_{3}$ and its precursors $\left(\mathrm{NO}\right.$ and $\left.\mathrm{NO}_{2}\right)$ was investigated thoroughly in urban environments [19,22,28-31]. However, very few studies considered modelling of ground level $\mathrm{O}_{3}$ [32-35]. In fact, $\mathrm{O}_{3}$ is involved in many chemical reactions that sometimes make its prediction very difficult. In this study, we present a simple statistical predictive model to calculate the steady-state daytime and nighttime $\mathrm{O}_{3}$ concentrations at an urban coastal site. For the purpose of model evaluation, we utilized a one-year data-base of ozone $\left(\mathrm{O}_{3}\right)$ and nitrogen oxides (NO and $\mathrm{NO}_{2}$ ) measured in Jeddah, which is located on the western part of Saudi Arabia [36]. Our model could be modified to evaluate ozone in other urban environments with similar diurnal patterns.

\section{Materials and Methods}

\subsection{Simple Statistical Predictive Model}

In the troposphere, ozone $\left(\mathrm{O}_{3}\right)$ and nitrogen oxides $\left(\mathrm{NO}_{x}\right)$ undergo a well-known null cycle in which each gaseous species maintains a steady-state concentration [37]; i.e., balanced production and loss rates balance each other (Figures 1-3). As postulated in the introduction, the daytime steady-state 
$\mathrm{O}_{3}$ concentration is higher than that during the nighttime steady-state concentrations. Furthermore, the chemical reactions involved with the $\mathrm{O}_{3}$ are different during both periods. Therefore, we postulate the simple predictive model for two time periods: Daytime and nighttime.

\subsection{Daytime Steady-State $\mathrm{O}_{3}$ Concentrations Prediction}

Under atmospheric conditions and in the presence of solar radiation $(\lambda<424 \mathrm{~nm})$, the $\mathrm{O}_{3}-\mathrm{NO}_{x}$ null cycle includes three successive reactions [37]:

$$
\begin{aligned}
& \mathrm{NO}_{2}+h v \rightarrow \mathrm{NO}+\mathrm{O}, \\
& \mathrm{O}+\mathrm{O}_{2}+\mathrm{M} \rightarrow \mathrm{O}_{3}+\mathrm{M}^{*}, \\
& \mathrm{O}_{3}+\mathrm{NO} \rightarrow \mathrm{NO}_{2}+\mathrm{O}_{2},
\end{aligned}
$$

where $M$ is an inert ground state (either $\mathrm{N}_{2}$ or $\mathrm{O}_{2}$ ) that acts as a surface for the reaction to take place and $M^{*}$ is the excited state of the molecule, $h v$ is the energy of the solar radiation photons that induces photochemical oxidation, $O$ is known to be highly reactive and disappears as soon as it is generated. Here, the concentration of $\mathrm{O}_{2}$ is assumed to be constant.

Under steady-state conditions, the null cycle has the steady-state formula,

$$
\frac{J_{\mathrm{NO}_{2}}}{k_{3}}=\frac{[\mathrm{NO}]\left[\mathrm{O}_{3}\right]}{\left[\mathrm{NO}_{2}\right]}
$$

where $J_{\mathrm{NO} 2}$ is the rate coefficient of $\mathrm{NO}_{2}$ photolysis, $k_{3}$ is the reaction rate coefficient of $\mathrm{O}_{3}$ and $\mathrm{NO}$. It is well known that the $k_{3}$ is temperature dependent [38]; $k_{3}=3.23 \exp (-1430 / \mathrm{T})$ in units of $\mathrm{ppb}^{-1} \mathrm{~min}^{-1}$. However, the seasonal temperature variation is few degrees; and therefore, we do not expect $k_{3}$ to have a considerable variation throughout the year in Jeddah.

Re-arrangement of Equation (2) yields a simple equation to predict the concentration of $\mathrm{O}_{3}$ from the ratio of $\mathrm{NO}_{2}$ to $\mathrm{NO}$ concentrations during daytime,

$$
\left[\mathrm{O}_{3}\right]=\alpha \frac{\left[N \mathrm{NO}_{2}\right]}{[\mathrm{NO}]}+\delta_{1}
$$

where $\alpha$ is a constant equivalent to $J_{\mathrm{NO} 2} / k_{3}$ and $\delta_{1}(\mathrm{ppb})$ is also constant related to the background $\mathrm{O}_{3}$ concentrations (e.g., migrates from the stratosphere to the troposphere, long-range transport, product of other reactions).

During daytime steady-state, using Equation (1):

$$
\frac{d\left[\mathrm{NO}_{2}\right]}{d t}=-J_{\mathrm{NO}_{2}}\left[\mathrm{NO}_{2}\right]+k_{3}\left[\mathrm{O}_{3}\right][\mathrm{NO}]=0,
$$

Upon rearranging we get Equation (2). We then compute a linear regression of $\left[\mathrm{O}_{3}\right]$ vs. $\left[\mathrm{NO}_{2} / \mathrm{NO}\right]$ of measured data. We, thus, are able to derive the constants for the model as $y=a x+b$ (Equation (3)), where $\mathrm{a}$ is a constant equivalent to $J_{\mathrm{NO} 2} / k_{3}$ and $\mathrm{b}$ is also constant related to the background $\mathrm{O}_{3}$ concentrations.

\subsection{Nighttime Steady-State $\mathrm{O}_{3}$ Concentrations Prediction}

During night-time hours, $\mathrm{O}_{3}$ is mainly consumed through its reaction with $\mathrm{NO}_{2}$,

$$
\mathrm{O}_{3}+\mathrm{NO}_{2} \rightarrow \mathrm{NO}_{3}+\mathrm{O}_{2}
$$

Applying reaction rate kinetics and rearrangement of the Equation (4) yields a simple equation to predict the nighttime $\mathrm{O}_{3}$ based on the concentration of its major nighttime sink compound $\mathrm{NO}_{2}$, 


$$
\left[\mathrm{O}_{3}\right]=\beta \frac{1}{\left[\mathrm{NO}_{2}\right]}-\delta_{2}
$$

where $\beta\left(\mathrm{ppb}^{2}\right)$ is a constant equivalent to the reaction rate of $\mathrm{O}_{3}$ with $\mathrm{NO}_{2}$ and $\delta_{2}(\mathrm{ppb})$ is again a constant related to the background $\mathrm{O}_{3}$ concentrations during the night.

During nighttime, Equation (4) steady state conditions are:

$$
\frac{d\left[\mathrm{O}_{3}\right]}{d t}=k_{\left(\mathrm{NO}_{2}, \mathrm{O}_{3}\right)}\left[\mathrm{O}_{3}\right]\left[\mathrm{NO}_{2}\right]=0,
$$

Upon rearranging we get Equations (6) and (7). We then compute a linear regression of $\left[\mathrm{O}_{3}\right]$ vs. $\left[\mathrm{NO}_{2}\right]$ of measured data. We, thus, are able to derive the constants for the model as $y=\mathrm{a} x+\mathrm{b}$ (Equation (3)), where a is a constant equivalent to $k$ (reaction rate of $\mathrm{O}_{3}$ with $\mathrm{NO}_{2}$ ) and $b$ is again a constant related to the background $\mathrm{O}_{3}$ concentrations.

\subsection{Data-Base}

In this study, we utilized a one-year data-base of $\mathrm{O}_{3}$ and $\mathrm{NO}_{x}$ concentrations measured at an urban site in Jeddah, Saudi Arabia between 1 January and 31 December 2012 [36]. The data-base is utilized to only evaluate the above described simple predictive model for steady-state $\mathrm{O}_{3}$ concentrations. The measurement was conducted at the King Abdul-Aziz University (KAU) campus, which is surrounded by major roads and a highway. Jeddah itself is situated on the west coast of Saudi Arabia and is considered the largest sea port on the Red Sea. Potential sources of air pollution in the city are mainly vehicle emissions (1.4 million vehicles; [39]) and industrial (oil refinery, desalination plant, power generation plant, and manufacturing industry). A lot of these emissions act as $\mathrm{O}_{3}$ precursors; under favored meteorological conditions and abundance of solar radiation, which are available in Jeddah.

\section{Results}

\subsection{Overview of the Daily Patterns}

The $\mathrm{O}_{3}$ concentrations showed a clear daily pattern with high concentrations during the daytime, which was as high as $39 \mathrm{ppb}$ and $47 \mathrm{ppb}$ on workdays (Saturday-Wednesday) and weekends (Friday), respectively (Figure 1). The nighttime (before 05:00) concentrations were between $7.5 \mathrm{ppb}$ and $13.2 \mathrm{ppb}$. As mentioned before in the introduction section, higher $\mathrm{O}_{3}$ concentrations on weekends daytime are not only attributed to the $N O_{x}$ cycle, but also possibly due to differences in the concentrations of other precursors (e.g., $\mathrm{CO}$ and $V O C$ ). The presence of $V O C s$ changes the path of $\mathrm{O}_{3}$ formation by altering the $\mathrm{NO}_{x}$ cycle mechanism through reactions of hydroxyl radicals, which in turn oxidize $N O$ without the use of $\mathrm{O}_{3}$. The latter, along with the photolysis of $\mathrm{NO}_{2}$, leads to accumulation of $\mathrm{O}_{3}$ during the daytime on weekends. Furthermore, when $\mathrm{NO}_{x}$ concentrations are high, the reaction of $\mathrm{NO}_{2}$ and $\mathrm{OH}$ to give $\mathrm{HNO}_{3}$ is favored [17], which reduces the $\mathrm{NO}_{2}$ concentrations available for photolysis. In turn, this leads to low photolysis rate $J_{\mathrm{NO} 2}$ during the weekends.

Recalling Equation (2), the daily pattern of $J_{\mathrm{NO} 2} / k_{3}$ (represented by the concentrations ratio $\left[\mathrm{O}_{3}\right][\mathrm{NO}] /\left[\mathrm{NO}_{2}\right]$ ) is characterized by a double peak (before noon and in the afternoon). The nighttime value varied between 0.5 and $1 \mathrm{ppb}$. The daytime value was as high as $5 \mathrm{ppb}$ on weekends and as high as 8 on workdays (Figure 4). As claimed before, $k_{3}$ does not have significant differences throughout the year in Jeddah; and thus, the daily pattern, shown in Figure 4, should represent the daily pattern of $J_{\mathrm{NO} 2}$. In general, $J_{\mathrm{NO} 2}$ is the rate of photolysis of $\mathrm{NO}_{2}$ and it seems to be lower on weekends than on workdays. In general, it has been well known that photolysis occurs more rapidly during lower PM (particulate matter) concentrations; This is mainly observed during the weekends [31,40]. The reason could be also referred to the change of both the $[\mathrm{NO}] /\left[\mathrm{NO}_{2}\right]$ ratio and the $\mathrm{O}_{3}$ concentration 
('weekend effect'). As shown in Figure 5, the daytime value of $[\mathrm{NO}] /\left[\mathrm{NO}_{2}\right]$ is higher on workdays than on weekends.

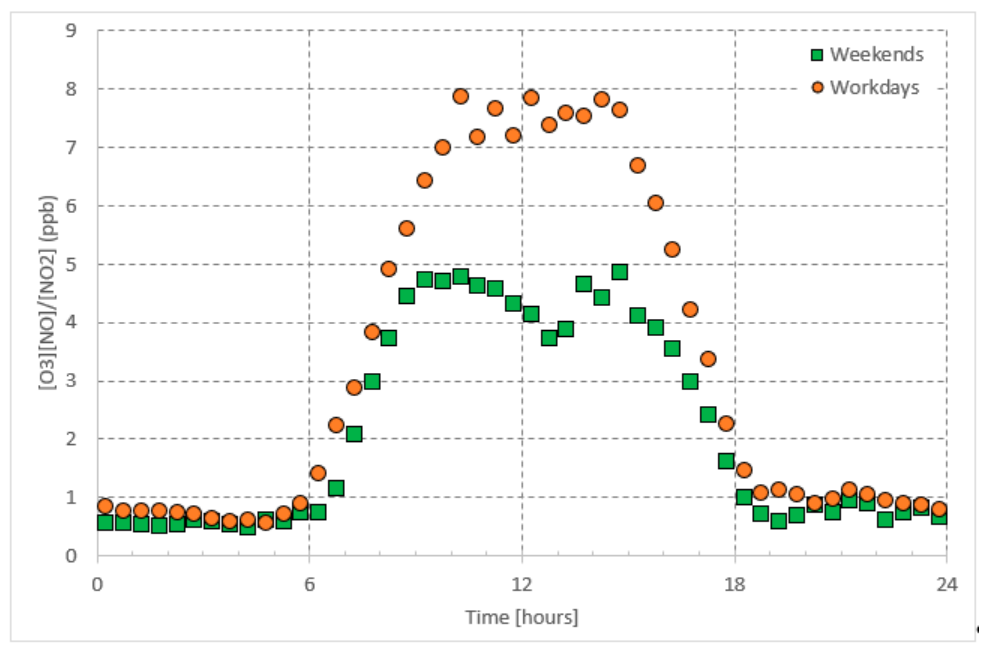

Figure 4. Average daily pattern of photo-stationary state concentrations $[\mathrm{NO}]\left[\mathrm{O}_{3}\right] /\left[\mathrm{NO}_{2}\right]$ presented separately for workdays and weekends.

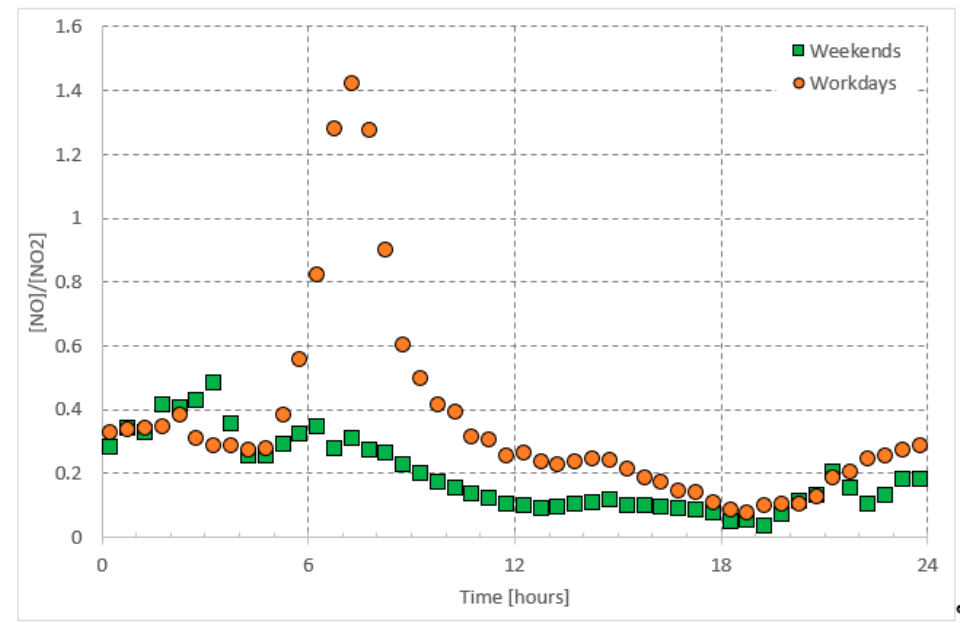

Figure 5. Average daily pattern of $[\mathrm{NO}] /\left[\mathrm{NO}_{2}\right]$ presented separately for workdays and weekends.

\subsection{Prediction of Steady-State $\mathrm{O}_{3}$ Concentration}

As shown in Figures 1-3, regarding the daily pattern of $\mathrm{O}_{3}$ and $\mathrm{NO}_{x}$, the steady-state conditions are met during 13:00-17:00 (referred to as daytime steady-state period) and 01:00-05:00 (referred to as nighttime steady-state period). We considered the 30-minutes average of the data-base and selected these time periods separately to apply the simple predictive model, which is a linear regression model. We applied the fitting to the whole data set. The nighttime period for all weekdays was considered as one period whereas the daytime period was considered separately for workdays (Saturday-Wednesday) and weekends (Friday).

The $\mathrm{O}_{3}$ concentration prediction for the daytime period according to Equation (3) is best represented by:

$$
\left[\mathrm{O}_{3}\right]_{\text {daytime }}= \begin{cases}1.09 \frac{\left[\mathrm{NO}_{2}\right]}{\mathrm{NO}}+29.35 & \text { Workdays }\left(R^{2}=0.37\right) \\ 0.50 \frac{\left[\mathrm{NO}_{2}\right]}{\mathrm{NO}}+35.47 & \text { Weekends }\left(R^{2}=0.31\right)\end{cases}
$$

The predicted $\mathrm{O}_{3}$ concentrations based on these equations are shown and compared to the measured ones in Figure 6. Note that the regression model parameters were obtained based on the 30-minutes average of the $\mathrm{O}_{3}$ and $N O_{x}$ data-base. In addition, the model predictions were also based 
on the 30-minutes average of the concentrations and Figure 6 is based on averaging the results to obtain the daily patterns.

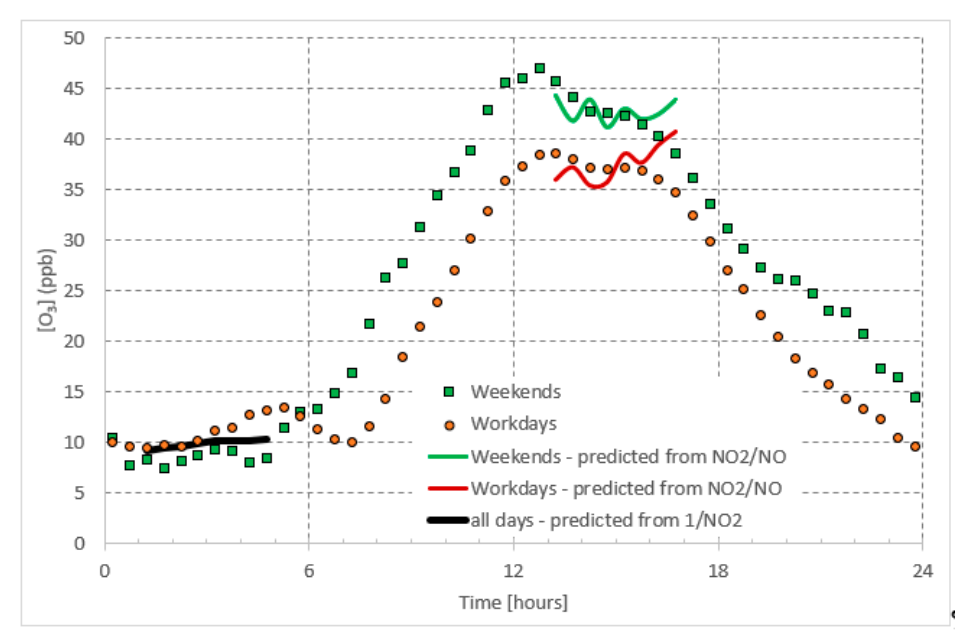

Figure 6. Prediction of daytime and night time $\mathrm{O}_{3}$ concentrations compared with the measured ones.

Based on Equation (6), the $\alpha$ constant, which is supposed to be equivalent to $J_{\mathrm{NO} 2} / k_{3}$, is found to be $1.09 \mathrm{ppb}$ and $0.50 \mathrm{ppb}$ for workdays and weekends daytime, respectively. The $\delta$ constant, which is related to the background ozone concentrations, is $29.35 \mathrm{ppb}$ and $35.47 \mathrm{ppb}$ for workdays and weekends, respectively. The theoretical value of $J_{\mathrm{NO} 2} / k_{3}$ calculated from the kinetics of the daytime reactions involved in $\mathrm{O}_{3}$ formation at steady-state are presented by the function is found to be $8.7 \mathrm{ppb}$. This can be easily verified for $J_{\mathrm{NO}}$ provided by ACOM online database (http:/ / cprm.acom.ucar.edu/ Models/TUV/Interactive_TUV/) and substituting $k_{3}$ as proposed with Equation (2).

This means that $\alpha$ value is different than the ideal one represented by $J_{\mathrm{NO} 2} / k_{3}$. Note that the kinetic model represents the ideal case, when the concentration of $\mathrm{O}_{3}$ depends solely on the $\mathrm{NO}_{x}-\mathrm{O}_{3}$ cycle with no contribution from additional sources or the involvement of other precursors in the $\mathrm{O}_{3}$ formation processes. Additionally, the ideal case occurs in full solar exposure, without factors leading to solar radiation attenuation, including daytime PM and cloudiness. Also note that the additional parameter $\delta_{1}$ can be thought of as a parameter that accounts for other processes contributing to the $\mathrm{O}_{3}$ formation in Jeddah. Interestingly, the value of $\delta_{1}$ is higher on weekends than on workdays. Other parameters which contribute to $\delta_{1}$ include long range transport of $\mathrm{O}_{3}$, as well as stratosphere-troposphere $\mathrm{O}_{3}$ migration. The latter is aided by the high temperature in Jeddah which enables this irreversible phenomenon to occur by increasing boundary layer height favoring proper mixing [41].

The $\mathrm{O}_{3}$ concentration prediction for the nighttime period according to Equation (5) is best represented by,

$$
\left[\mathrm{O}_{3}\right]_{\text {nighttime }}=\frac{267.01}{\left[\mathrm{NO}_{2}\right]}+1.16 \quad \text { All days }\left(R^{2}=0.58\right)
$$

The predicted $\mathrm{O}_{3}$ concentrations are also shown and compared to the measured ones in Figure 6 . Again, the regression model parameters were obtained based on the 30-minutes average of the $\mathrm{O}_{3}$ and $N O_{x}$ data-base.

This equation is based on the fact that $\mathrm{NO}_{2}$ acts as a major sink for the night-time $\mathrm{O}_{3}$ [24]. Here the parameter $\beta$ can be thought of as the reaction rate of $\mathrm{O}_{3}$ with $\mathrm{NO}_{2}$. In our analysis, $\beta$ is rather similar for all days of the week and its value is about $267 \mathrm{ppb}^{2}$. The second parameter $\delta_{2}$ has a value of $1.16 \mathrm{ppb}$. The theoretical value for the reaction rate of $\mathrm{O}_{3}$ with $\mathrm{NO}_{2}$ during nighttime is about $1250 \mathrm{ppb}^{2}$ [42-44]. Again, the deviations between $\beta$ and the reaction rate of $\mathrm{O}_{3}$ with $\mathrm{NO}_{2}$ during nighttime can be explained by the occurrence of additional sinks of ozone, including surface reactions of particulate matter and deposition [24]. 


\section{Conclusions}

In this study, we suggested a simple statistical predictive model to calculate the steady-state daytime and nighttime $\mathrm{O}_{3}$ concentrations at an urban coastal site. This model was formulated based on a modified approach of the null cycle of $\mathrm{O}_{3}$ and $\mathrm{NO}_{x}$. The model evaluation was performed by utilizing a one-year data-base of ozone $\left(\mathrm{O}_{3}\right)$ and nitrogen oxides $\left(\mathrm{NO}\right.$ and $\left.\mathrm{NO}_{2}\right)$ measured in Jeddah, which is located on the west coast of Saudi Arabia. The steady-state conditions for $\mathrm{O}_{3}$ and $\mathrm{NO}_{x}$ at this site were observed during daytime (13:00-17:00) and nighttime (01:00-05:00).

The simple model for daytime concentrations was proposed to be linearly dependent on the concentration ratio of $\mathrm{NO}_{2}$ to $\mathrm{NO}$ whereas that for the nighttime period it was suggested to be inversely proportional to $\mathrm{NO}_{2}$ concentrations. Since the daytime $\mathrm{O}_{3}$ concentrations on workdays (Saturday-Wednesday) were lower than those on weekends (Friday), two separate formulas were suggested for the daytime concentration predictions. Recalling the complex reactions involved in tropospheric $\mathrm{O}_{3}$ formation, this proposed simple model provided reasonable predictions for the daytime and nighttime concentrations. Since the current description of the model is solely based on null cycle of $\mathrm{O}_{3}$ and $\mathrm{NO}_{x}$, other precursors should be considered in future development of this simple model.

Our study could be applied to several urban environments with similar emission patterns, as well as fill the gaps in $\mathrm{O}_{3}$ data when no measurements were collected. Our study could also serve as basis for future studies for enforcing strategies to control ground level $\mathrm{O}_{3}$ concentrations, as well as its precursors' emissions in polluted environments.

Author Contributions: Conceptualization, T.H., L.D., A.A.-H. and S.A.; Methodology, T.H. and L.D., A.A.-H.; Software, L.D., T.H., and M.A.Z.; Validation, L.D., T.H. and M.A.Z.; Formal Analysis, A.S.A., T.H., and L.D.; Investigation, M.K., H.A.-J., M.A.A., H.L., A.H., and T.H.; Resources, A.S.A., I.I.S., and F.M.A.; Data Curation, A.S.A., I.I.S., and F.M.A.; Writing-Original Draft Preparation, M.A.A., L.D. and T.H.; Writing-Review and Editing, M.A.A., L.D. and T.H.; Visualization, L.D., T.H. and M.A.Z.; Supervision, T.H.; Project Administration, M.K., H.A.-J., M.A.A., H.L., A.H., and T.H.; Funding Acquisition, H.A.-J. and M.A.A.

Funding: This research was funded by Deanship of Scientific Research (DSR) at King Abdulaziz University, Jeddah, under grant no. (I-122-30). The authors acknowledge with thanks DSR for technical and financial support. This study was also supported by the Academy of Finland Center of Excellence (grant no. 272041) and doctoral program in atmospheric sciences (ATM-DP).

Conflicts of Interest: The authors declare no conflict of interest.

\section{References}

1. WHO. Health and Health Behaviour among Young People: Health Behaviour in School-Aged Children: A WHO Cross-National Study (HBSC), International Report; WHO: Geneva, Switzerland, 2000.

2. IPCC. 2007: Summary for policymakers. In Climate Change 2007: Impacts, Adaptation and Vulnerability. Contribution of Working Group II to the Fourth Assessment Report of the Intergovernmental Panel on Climate Change; Cambridge University Press: Cambridge, UK, 2007; pp. 93-129.

3. Thompson, A.M. The oxidizing capacity of the Earth's atmosphere: Probable past and future changes. Science 1992, 256, 1157-1165. [CrossRef] [PubMed]

4. Laurila, T. Observational study of transport and photochemical formation of ozone over northern Europe. J. Geophys. Res. Atmos. 1999, 104, 26235-26243. [CrossRef]

5. Solomon, P.; Cowling, E.; Hidy, G.; Furiness, C. Comparison of scientific findings from major ozone field studies in North America and Europe. Atmos. Environ. 2000, 34, 1885-1920. [CrossRef]

6. Thompson, A.M.; Witte, J.C.; Hudson, R.D.; Guo, H.; Herman, J.R.; Fujiwara, M. Tropical tropospheric ozone and biomass burning. Science 2001, 291, 2128-2132. [CrossRef] [PubMed]

7. Pereira, M.; Alvim-Ferraz, M.; Santos, R. Relevant aspects of air quality in Oporto (Portugal): PM10 and O3. Environ. Monit. Assess. 2005, 101, 203-221. [PubMed]

8. Tecer, L.; Ertürk, F.; Cerit, O. Development of a regression model to forecast ozone concentration in Istanbul City, Turkey. Fresenius Environ. Bull. 2003, 12, 1133-1143. 
9. Olszyna, K.; Luria, M.; Meagher, J. The correlation of temperature and rural ozone levels in southeastern USA. Atmos. Environ. 1997, 31, 3011-3022. [CrossRef]

10. Vingarzan, R.; Taylor, B. Trend analysis of ground level ozone in the greater Vancouver/Fraser Valley area of British Columbia. Atmos. Environ. 2003, 37, 2159-2171. [CrossRef]

11. Vukovich, F.M.; Sherwell, J. An examination of the relationship between certain meteorological parameters and surface ozone variations in the Baltimore-Washington corridor. Atmos. Environ. 2003, 37, 971-981. [CrossRef]

12. Ribas, À.; Peñuelas, J. Temporal patterns of surface ozone levels in different habitats of the North Western Mediterranean basin. Atmos. Environ. 2004, 38, 985-992. [CrossRef]

13. García, M.; Sánchez, M.; Pérez, I.; De Torre, B. Ground level ozone concentrations at a rural location in northern Spain. Sci. Total Environ. 2005, 348, 135-150. [CrossRef]

14. Dueñas, C.; Fernández, M.; Cañete, S.; Carretero, J.; Liger, E. Assessment of ozone variations and meteorological effects in an urban area in the Mediterranean Coast. Sci. Total Environ. 2002, 299, 97-113. [CrossRef]

15. Alvim-Ferraz, M.; Sousa, S.; Pereira, M.; Martins, F. Contribution of anthropogenic pollutants to the increase of tropospheric ozone levels in the Oporto Metropolitan Area, Portugal since the 19th century. Environ. Pollut. 2006, 140, 516-524. [CrossRef] [PubMed]

16. Pudasainee, D.; Sapkota, B.; Shrestha, M.L.; Kaga, A.; Kondo, A.; Inoue, Y. Ground level ozone concentrations and its association with NOx and meteorological parameters in Kathmandu valley, Nepal. Atmos. Environ. 2006, 40, 8081-8087. [CrossRef]

17. Sillman, $\mathrm{S}$. The use of $\mathrm{NOy}, \mathrm{H} 2 \mathrm{O} 2$, and $\mathrm{HNO} 3$ as indicators for ozone-NOx-hydrocarbon sensitivity in urban locations. J. Geophys. Res. 1995, 100, 14175-114188. [CrossRef]

18. Nevers, N. Control of volatile organic compounds (VOCs). Air Pollut. Control Eng. 2000, 18, 329-330.

19. Sillman, $\mathrm{S}$. The relation between ozone, $\mathrm{NO} \mathrm{x}$ and hydrocarbons in urban and polluted rural environments. Atmos. Environ. 1999, 33, 1821-1845. [CrossRef]

20. Guicherit, R.; Roemer, M. Tropospheric ozone trends. Chemosphere-Glob. Chang. Sci. 2000, 2, 167-183. [CrossRef]

21. Tang, W.; Zhao, C.; Geng, F.; Peng, L.; Zhou, G.; Gao, W.; Xu, J.; Tie, X. Study of ozone "weekend effect" in Shanghai. Sci. China Ser. D Earth Sci. 2008, 51, 1354-1360. [CrossRef]

22. Song, F.; Shin, J.Y.; Jusino-Atresino, R.; Gao, Y. Relationships among the springtime ground-level $\mathrm{NO}_{X}, \mathrm{O}_{3}$ and $\mathrm{NO}_{3}$ in the vicinity of highways in the US East Coast. Atmos. Pollut. Res. 2011, 2, 374-383. [CrossRef]

23. Domínguez-López, D.; Adame, J.; Hernández-Ceballos, M.; Vaca, F.; De la Morena, B.; Bolívar, J. Spatial and temporal variation of surface ozone, $\mathrm{NO}$ and $\mathrm{NO}_{2}$ at urban, suburban, rural and industrial sites in the southwest of the Iberian Peninsula. Environ. Monit. Assess. 2014, 186, 5337-5351. [CrossRef] [PubMed]

24. Finlayson-Pitts, B.J.; Pitts, J.N., Jr. Chemistry of the Upper and Lower Atmosphere: Theory, Experiments, and Applications; Academic Press: Cambridge, MA, USA, 1999.

25. Rao, T.; Reddy, R.; Sreenivasulu, R.; Peeran, S.; Murthy, K.; Ahammed, Y.; Gopal, K.; Azeem, P.; Sreedhar, B.; Sunitha, K. Air space pollutants CO and NOx level at Anantapur (semi-arid zone), Andhra Pradesh. J. Indian Geophys. Union 2002, 3, 151-161.

26. Rao, T.; Reddy, R.; Sreenivasulu, R.; Peeran, S.; Murthy, K.; Ahammed, Y.; Gopal, K.; Azeem, P.; Sreedhar, B.; Badarinath, K. Seasonal and diurnal variations in the levels of NOx and CO trace gases at Anantapur in Andhra Pradesh. J. Indian Geophys. Union 2002, 3, 163-168.

27. Vingarzan, R. A review of surface ozone background levels and trends. Atmos. Environ. 2004, 38, 3431-3442. [CrossRef]

28. Chameides, W.; Fehsenfeld, F.; Rodgers, M.; Cardelino, C.; Martinez, J.; Parrish, D.; Lonneman, W.; Lawson, D.; Rasmussen, R.; Zimmerman, P. Ozone precursor relationships in the ambient atmosphere. J. Geophys. Res. Atmos. 1992, 97, 6037-6055. [CrossRef]

29. Lal, S.; Naja, M.; Subbaraya, B. Seasonal variations in surface ozone and its precursors over an urban site in India. Atmos. Environ. 2000, 34, 2713-2724. [CrossRef]

30. Mazzeo, N.A.; Venegas, L.E.; Choren, H. Analysis of $\mathrm{NO}, \mathrm{NO}_{2}, \mathrm{O}_{3}$ and $\mathrm{NO}_{\mathrm{x}}$ concentrations measured at a green area of Buenos Aires City during wintertime. Atmos. Environ. 2005, 39, 3055-3068. [CrossRef]

31. Han, S.; Bian, H.; Feng, Y.; Liu, A.; Li, X.; Zeng, F.; Zhang, X. Analysis of the Relationship between $\mathrm{O}_{3}, \mathrm{NO}$ and $\mathrm{NO}_{2}$ in Tianjin, China. Aerosol Air Qual. Res. 2011, 11, 128-139. [CrossRef] 
32. Abdul-Wahab, S.A.; Bakheit, C.S.; Al-Alawi, S.M. Principal component and multiple regression analysis in modelling of ground-level ozone and factors affecting its concentrations. Environ. Model. Softw. 2005, 20, 1263-1271. [CrossRef]

33. Sousa, S.; Martins, F.; Alvim-Ferraz, M.; Pereira, M.C. Multiple linear regression and artificial neural networks based on principal components to predict ozone concentrations. Environ. Model. Softw. 2007, 22, 97-103. [CrossRef]

34. Özbay, B.; Keskin, G.A.; Doğruparmak, Ş.Ç.; Ayberk, S. Multivariate methods for ground-level ozone modeling. Atmos. Res. 2011, 102, 57-65. [CrossRef]

35. Varotsos, C.; Ondov, J.; Efstathiou, M. Scaling properties of air pollution in Athens, Greece and Baltimore, Maryland. Atmos Environ. 2005, 39, 4041-4047.

36. Alghamdi, M.; Khoder, M.; Harrison, R.M.; Hyvärinen, A.-P.; Hussein, T.; Al-Jeelani, H.; Abdelmaksoud, A.; Goknil, M.; Shabbaj, I.; Almehmadi, F. Temporal variations of $\mathrm{O}_{3}$ and $\mathrm{NO}_{\mathrm{x}}$ in the urban background atmosphere of the coastal city Jeddah, Saudi Arabia. Atmos. Environ. 2014, 94, 205-214. [CrossRef]

37. Leighton, P. Photochemistry of Air Pollution; Elsevier: New York, NY, USA, 2012.

38. Seinfeld, J.H.; Pandis, S.N. Atmospheric Chemistry and Physics: From Air Pollution to Climate Change; John Wiley \& Sons: Hoboken, NJ, USA, 2016.

39. Khodeir, M.; Shamy, M.; Alghamdi, M.; Zhong, M.; Sun, H.; Costa, M.; Chen, L.-C.; Maciejczyk, P. Source apportionment and elemental composition of PM2. 5 and PM10 in Jeddah City, Saudi Arabia. Atmos. Pollut. Res. 2012, 3, 331. [CrossRef] [PubMed]

40. Marr, L.C.; Harley, R.A. Modeling the effect of weekday-weekend differences in motor vehicle emissions on photochemical air pollution in central California. Environ. Sci. Technol. 2002, 36, 4099-4106. [CrossRef]

41. Kuang, S.; Newchurch, M.; Burris, J.; Wang, L.; Knupp, K.; Huang, G. Stratosphere-to-troposphere transport revealed by ground-based lidar and ozonesonde at a midlatitude site. J. Geophys. Res. Atmos. 2012, 117. [CrossRef]

42. Cox, R.; Coker, G. Kinetics of the reaction of nitrogen dioxide with ozone. J. Atmos. Chem. 1983, 1, 53-63. [CrossRef]

43. Huie, R.E.; Herron, J.T. The rate constant for the reaction $\mathrm{O}_{3}+\mathrm{NO}_{2} \rightarrow \mathrm{O}_{2}+\mathrm{NO}_{3}$ over the temperature range 259-362 K. Chem. Phys. Lett. 1974, 27, 411-414. [CrossRef]

44. Johnston, H.S.; Graham, R. Photochemistry of $\mathrm{NO}_{\mathrm{x}}$ and $\mathrm{HNO}_{\mathrm{x}}$ compounds. Can. J. Chem. 1974, 52, 1415-1423. [CrossRef] 